\title{
COMMENTS ON THE ARTICLE "MONITORING COVID-19 IS LIKE INSTRUMENT FLYING"
}

\author{
David D. Pokrajac \\ Delaware State University, \\ Department of Computer and Information Sciences, \\ Dover, USA; \\ University of Niš, Faculty of Science and Mathematics, \\ Department of Computer Science, \\ Niš, Republic of Serbia, \\ e-mail: majstorpoki@gmail.com, \\ ORCID iD: (Dhttps://orcid.org/0000-0002-8362-1245
}

DOI: 10.5937/vojtehg69-32707; https://doi.org/10.5937/vojtehg69-32707

FIELD: Mathematics

ARTICLE TYPE: Letter to the Editor

\section{Dear Editor of the Military Technical Courier,}

I have read the article "Monitoring COVID-19 is like instrument flying" by Petar V. Kočović, University Union "Nikola Tesla", School for Information Technology and Engineering, Zoran V. Kočović, Omni Logika, and Vladimir P. Kočović, IGT, all from Belgrade, published in Vojnotehnički glasnik/Military Technical Courier Vol. 68, No. 3, pp.424437, doi: https://doi.org/10.5937/vojtehg68-26557. I would like to share with you and the audience of your Journal my professional opinion about the article. Note the opinion expressed is my personal, and as such does not reflect nor communicate the opinion or viewpoints of my employer or any professional or other organizations I may belong to. Note also that prior to communicating to your journal, I have attempted to obtain clarifications directly from the first author, but with no success.

The purpose of the article is to propose the methodology to predict the duration of a Covid-19 epidemic wave (and potentially applicable to any other epidemics of infectious deceases). The central assumption of the article is that the number of new cases per day follows a simple curve (a Gaussian curve) and that, by using the number of cases from the left 
tail of the curve, we can predict the parameters of the curve. The second assumption is that the epidemic wave can be considered over when the input variable (time) is several standard deviations away from the estimated center of the Gaussian curve on its left tail.

Based on the Statement of the Journal Purpose (as cited from http://www.vtg.mod.gov.rs/about-journal.html:

"The journal publishes scientific and professional papers covering fundamental research (mathematics, computer science and mechanics) and technological development (electronics, telecommunications, information technologies, mechanical engineering, material science and chemical technologies) as well as technical data on modern weapon systems and military technologies."), the article may be out of scope of the Journal.

My professional opinion is that the article is methodologically weak.

The central assumptions of the article, as I summarized them above, have never been clearly stated nor justified. The authors claim, page 428:

"The infections start outgrowing exponentially at first, then whatever response the host country enacts, after some time, new infections go back to near zero. At least this is the back-of-the-envelope theory, developed by Enrico Fermi."

No reference for this was provided. However, I was able to find an Internet article https://towardsdatascience.com/the-gaussian-model4a94a2b3ff1b that contains a figure identical to Fig. 4 of the paper in question as well as the identical sentence as quoted from the paper (see above). Eq. (3) from the paper also appears in the Internet article and is not as such referenced in this paper. Note that the publication date of the Internet article is $3 / 25 / 2020$. I could not determine the exact submission date of the paper in question. However, since the paper discusses actual data from May 10, 2020, this paper was very likely submitted later than the Internet publication containing the same graph and the same sentence, which was not referred to in the paper. Also, the figure identical to Fig. 5 of the paper can be found on the Internet, at http://deptche.ccu.edu.tw/exam/104phychem.pdf. My opinion is that these question the originality of the approach and the paper itself as published in your Journal. 


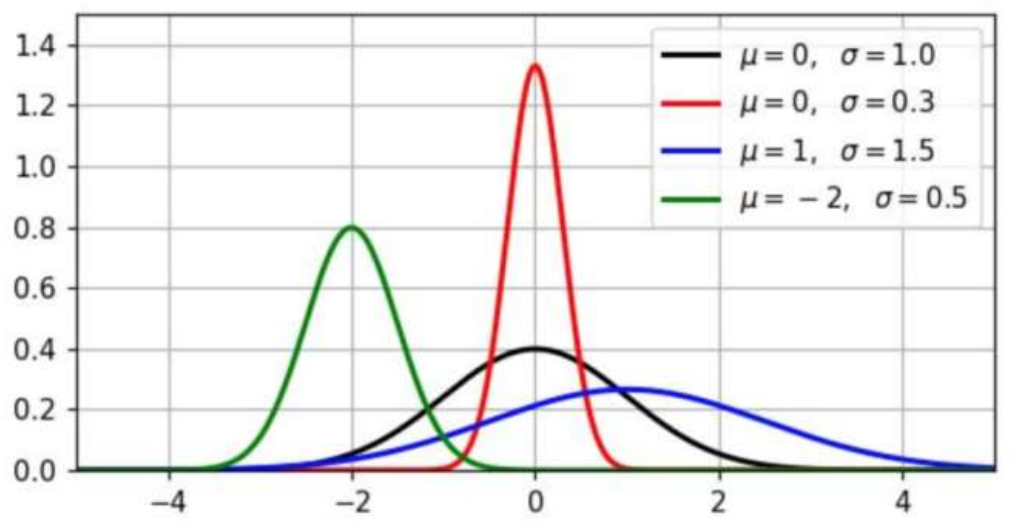

Figure 4- The Normal, or the Gaussian curve

Puc. 4 - Кривая нормального распределения Гаусса Слика 4 - Нормална или Гаусова крива

Figure 1 - Figure 4 from Kočović et al, submitted on or after 5/10/2020

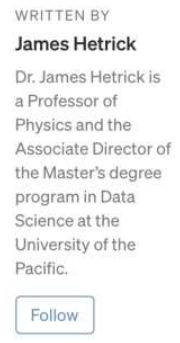

(19) 91

Q 4

ロ

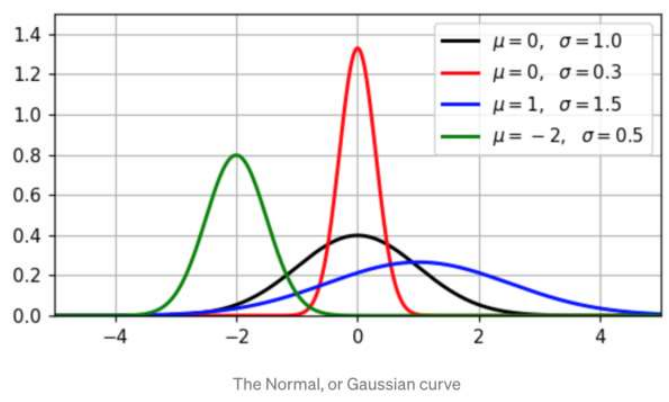

The infections start out growing exponentially at first, then whatever response the host country enacts, after some time, new infections go back to near zero. At least that's the back-of-the-envelope theory. Surely there are better models, but we'll use the Gaussian model as a first shot.

Figure 2 - Figure and text published on the Internet 3/25/2020 


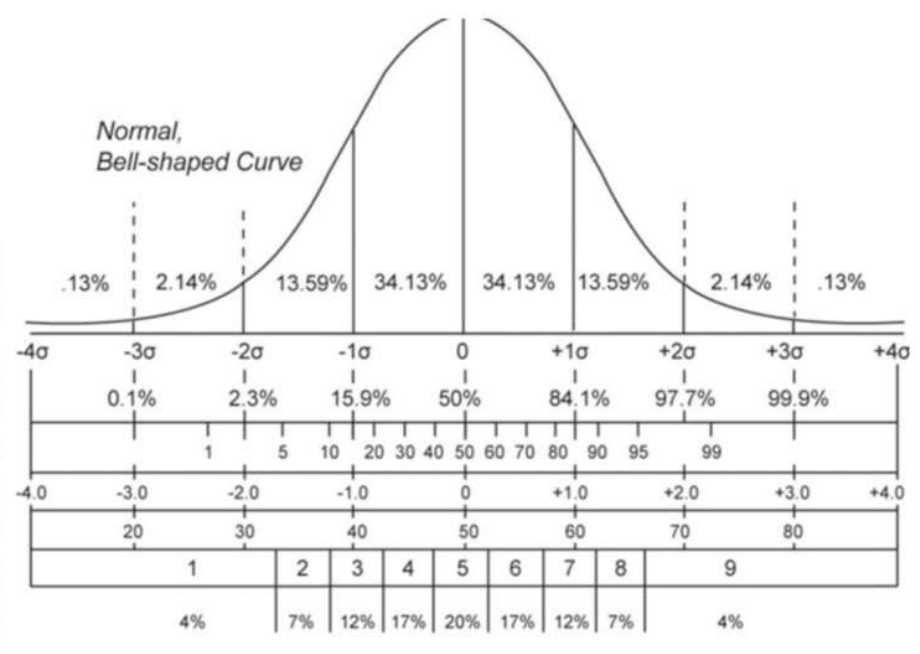

Figure 5 - Gaussian distribution extended to 8 SIGMA

Puc. 5 - Кривая распределения Гаусса расширена за 8 СИГМ Слика 5 - Гаусова расподела проширена на 8 СИГМА

Figure 3 - Fig. 5 from Kočović et al

deptche.ccu.edu.tw/exam/104phychem.pdf

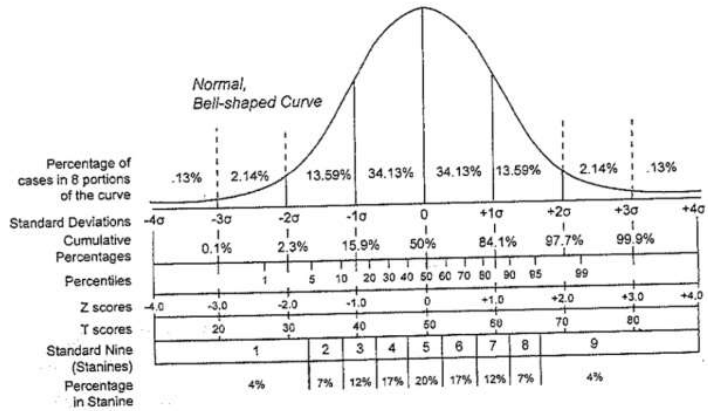

Figure 4 - A figure, identical to Fig. 5 from Kočović et al, can be found on the Internet

Generally, the article does not seem to contain model validation. It is not clear how well the model determines the end of an epidemic wave. Specifically, according to the article (page 430), "The forecasted day of 
the $7 \sigma$ is May 26, 2020"; however, it is not possible to determine the accuracy of this prediction based on the article.

Further, the authors make several claims that are not substantiated nor supported by references. On page 429, they state:

"A mathematical model can calculate the whole distribution if histograms are covered with more than $50 \%$ of the data"

and later, on the same page:

"The algorithm calculates distribution if the minimum 3 SIGMA conditions are fulfilled, and there are no extreme peaks in one day."

It is not clear how "3 SIGMA conditions" are checked and where the condition is defined. Further in the paper, the authors introduce "7-sigma day" (pages 430 and 433) and "8-sigma" model (page 429) but there is no indication whether here $7(8)$ relates to the width of the symmetric interval around the center of the curve (i.e., corresponding to \pm 3.5 sigma, \pm 4 sigma) as could be deduced from Fig, 5. Since the important prediction of the end of the epidemic is based on the definition of this criterion, the criterion should have been explicitly and exactly defined in the article.

The following sentences on page 432 are not clear:

"The Gaussian curve can calculate the date of the end of the epidemic with a probability of $99.9996 \%$. This means that the chances are ONE in a MILLION for citizens to become ill with COVID19 after the Gaussian distribution has ended."

Specifically, how the probability of $99.9996 \%$ is related to $1 / 1,000,000$ odds and what is the meaning of "after he Gaussian distribution has ended" i.e. how the distribution can "end"? 431-2:

It is not clear why the (logistic) sigmoid has been introduced, pages

"On the other hand, the authors found a link between Gaussian and Boltzmann or Sigmoid (S) curves."

If the authors needed a definite integral of a Gaussian curve, they could have expressed it using the erf function which can be easily numerically calculated.

The authors introduce a "double logarithmic curve" to link the number of newly infected daily and the cumulative number of the infected. It is not well justified why such a graph is needed and how the "7-sigma" criterion could be satisfied in Fig. 7d but not be satisfied in Fig. 9a (since the same data with different representations are used).

The source for the data shown in Figs. 1,2,3,7,8,and 9 is not specified. Similarly, the source for the Serbian data (page 430) is not 
specified. When discussing the results for Serbia, it is not defined what "Accuracy of the Gaussian model" is (seems to be the ratio between the cumulative number of the infected as estimated by the model and the true number of cases) nor it is clear what the consequence of the obtained value is (whether the accuracy is good or bad and why). The "area fraction" is not well defined.

The authors utilize the terminology which may not be appropriate. What was shown in Figs. 2 and 3 are not histograms but bar plots. Similarly, a "double logarithmic curve" is in fact a log-log plot. The authors claim, page 429, that "the alternative names for the Gaussian distribution are 6 SIGMA or LEAN 6 SIGMA" which does not seem to be correct. Also, some language in the article (footnote, page 428, "The term Back of the envelope calculation is a rough calculation. It is more than a guess, but less than a mathematical proof.", page 430: "As it is shown, the model can predict, mathematically, the end of the epidemic. But, one thing is mathematics, another is real life", as well as the title of the article "MONITORING COVID-19 IS LIKE INSTRUMENT FLYING") is imprecise and colloquial and as such should be avoided in scientific communication.

I strongly believe that the publication of these Comments in your esteemed Journal is necessary part of scientific communication and will contribute to the quality of the Journal and help your readership.

КРИТИЧЕСКИЙ ОБЗОР СТАТЬИ «MONITORING COVID-19 IS LIKE INSTRUMENT FLYING»

Давид Д. Покраяц

Государственный Делавэрский университет, департамент компьютерных и информационных наук, г. Довер, США;

Нишский университет, естественно-математический факультет, департамент компьютерных наук,

г. Ниш, Республика Сербия

РУБРИКА ГРНТИ: 27.00.00 МАТЕМАТИКА;

27.43.17 Математическая статистика,

27.43.51 Применение теоретико-вероятностных и

ВИД СТАТЬИ: письмо редактору статистических методов 
КРИТИЧКИ ОСВРТ НА ЧЛАНАК "MONITORING COVID-19 IS LIKE INSTRUMENT FLYING"

Давид Д. Покрајац

Државни универзитет у Делаверу,

Департман за рачунарске и информационе науке,

Довер, САД;

Универзитет у Нишу, Природно-математички фракултет,

Департман за рачунарске науке,

Ниш, Република Србија

ОБЛАСТ: математика

ВРСТА ЧЛАНКА: писмо уреднику

Paper received on / Дата получения работы / Датум пријема чланка: 10.06.2021. Manuscript corrections submitted on / Дата получения исправленной версии работы / Датум достављања исправки рукописа: 22.06.2021.

Paper accepted for publishing on / Дата окончательного согласования работы / Датум коначног прихватања чланка за објављивање: 24.06.2021.

(c) 2021 The Author. Published by Vojnotehnički glasnik / Military Technical Courier (www.vtg.mod.gov.rs, втг.мо.упр.срб). This article is an open access article distributed under the terms and conditions of the Creative Commons Attribution license (http://creativecommons.org/licenses/by/3.0/rs/).

(c) 2021 Автор. Опубликовано в «Военно-технический вестник / Vojnotehnički glasnik / Military Technical Courier» (www.vtg.mod.gov.rs, втг.мо.упр.срб). Данная статья в открытом доступе и распространяется в соответствии с лицензией «Creative Commons» (http://creativecommons.org/licenses/by/3.0/rs/).

() 2021 Аутор. Објавио Војнотехнички гласник / Vojnotehnički glasnik / Military Technical Courier (www.vtg.mod.gov.rs, втг.мо.упр.срб). Ово је чланак отвореног приступа и дистрибуира се у складу са Creative Commons licencom (http://creativecommons.org/licenses/by/3.0/rs/). 